\title{
Transoral robotic surgery in Eagle's syndrome: our experience on four patients
}

\author{
La chirurgia robotica transorale nella sindrome di Eagle: \\ nostra esperienza su quattro pazienti \\ D.H. KIM, Y.H. LEE, D. CHA, S.H. KIM \\ ${ }^{1}$ Department of Otorhinolaryngology, Severance Hospital, Yonsei University College of Medicine, Seoul, Korea
}

\begin{abstract}
SUMMARY
Eagle's syndrome is characterised by focal pain in the tonsillar fossa on wide mouth opening or head rotation and various accompanying symptoms. While the syndrome is difficult to diagnose, shortening the styloid process via a transoral or transcervical surgical approach has been shown to be the most effective treatment. The aim of this article was to document our experience with a transoral robotic approach to treat Eagle's syndrome and to present the outcomes of four patients. We reviewed the cases of four patients with Eagle's syndrome who underwent transoral robotic surgery (TORS). The average age of patients was 53.75 years, and there were equal numbers of males and females. The styloid processes were reconstructed in 3D from the preoperative CT scans and were measured as an average of $4.18 \mathrm{~cm}$ (range 3.3-5.1). The mean set-up time and operation times were less than 10 minutes and 30 minutes, respectively. All patients were completely relieved of symptoms, and were able to restart an oral diet on post-operative day 1 . No patient suffered intraoperative or postoperative complication, including cranial nerve injury, haemorrhage, or deep neck infection. In our experience, transoral excision of the styloid process via a robotic approach can be considered as a feasible treatment option for Eagle's syndrome.
\end{abstract}

KEY WORDS: Robotics • Eagle's syndrome • Transoral robotic surgery

\section{RIASSUNTO}

La sindrome di Eagle è caratterizzata da dolore a livello della loggia tonsillare all'apertura della bocca o alla rotazione della testa, e da vari altri sintomi associati. Nonostante la sindrome sia difficile da diagnosticare, è stato osservato che l'accorciamento del processo stiloideo per via transorale o trancervicale è il trattamento più efficace. L'obiettivo di questo studio è stato quello di portare la nostra esperienza con la chirurgia robotica transorale nel trattamento della sindrome di Eagle, presentando i risultati di quattro pazienti. Abbiamo dunque revisionato i casi di quattro pazienti con Sindrome di Eagle sottoposti a chirurgia robotica transorale (TORS). L'età media dei pazienti era 53.75, e i due sessi erano rappresentati in ugual misura. I processi stiloidei sono stati ricostruiti in $3 D$ a partire dalle scansioni TC preoperatorie e sono stati misurati: la media è risultata pari a $4.18 \mathrm{~cm}$ (range $3.3-5.1 \mathrm{~cm}$ ). I tempi medi di preparazione e di intervento sono risultati pari a 10 e 30 minuti rispettivamente. Tutti i pazienti hanno avuto una completa risoluzione dei sintomi e tutti hanno ripreso la dieta orale in prima giornata postoperatoria. Non c'è stata nessuna complicanza intraoperaatoria o postoperatoria, come emorragie, infezioni o lesioni di nervi cranici. Dalla nostra esperienza si evince che l'accorciamento del processo stiloideo con chirurgia robotica transorale può essere una valida opzione per il trattamento della sindrome di Eagle.

PAROLE CHIAVE: Chirurgia robotica transorale $($ TORS $) \bullet$ Sindrome di Eagle

Acta Otorhinolaryngol Ital 2017;37:454-457

\section{Introduction}

Eagle's syndrome was first described by Watt W. Eagle in 1937 as the symptomatic elongation of the styloid process or mineralisation (ossification or calcification) of the stylohyoid ligament complex ${ }^{12}$. The syndrome is characterised by focal pain in the tonsillar fossa on wide mouth opening or head rotation and various accompanying symptoms such as a foreign body sensation in the throat, dysphagia and odynophagia.

The aetiology of this disease is unknown, although it is presumed to be caused by impingement of the styloid pro- cess on the internal/external carotid arteries, involving the nerve plexus ${ }^{23}$.

Due to variable and nonspecific symptoms, the syndrome is difficult to diagnose; thus, its prevalence is underestimated in the population. However, once a correct diagnosis is made, shortening the styloid process via a transoral or transcervical surgical approach has been shown to be the most satisfactory and effective treatment ${ }^{4}$.

The aim of this article was to document our experience with a transoral robotic approach to treat Eagle's syndrome and to present the outcomes of four patients. 


\section{Materials and methods}

\section{Patient population}

We reviewed the cases of four patients with Eagle's syndrome who underwent transoral robotic surgery (TORS) at Yonsei Head and Neck Cancer Center, Severance Hospital, a tertiary care medical centre, from March 2011 to December 2013. All patients complained of throat pain as the major symptom. One of the patients had undergone previous tonsillectomy. The diagnostic work-up was completed with 3-dimensional computed tomography $(\mathrm{CT})$ reconstruction. Intraoperative time, estimated blood loss, days of hospital stay and cosmetic satisfaction survey were collected and analysed for all four patients.

\section{Surgical procedures}

The configuration of the operating room and of the $\mathrm{Si}$ da Vinci robotic system (Intuitive Surgical Inc., Sunny- vale, CA) used to conduct TORS have been previously established by robotic surgeons ${ }^{5-7}$. The operation was performed under general anesthesia with the patient in the Rose position. A Crowe-Davis mouth gag retractor (Storz, Munich, Germany) was applied for better transoral exposure. A $0^{\circ}$ endoscope was used to visualise the surgical field, and two robotic instrument arms, equipped at both sides of the endoscopic arm with 5-mm Maryland forceps and 5-mm spatula monopolar cautery, were utilised throughout the operation (Fig. 1A) ${ }^{7}$. The assistant handled the suction equipment and rongeur forceps.

After palpating the elongated styloid process, the location of the lesion is marked on the oral mucosa, and a peritonsillar mucosa incision was placed $1 \mathrm{~cm}$ lateral to the anterior pillar ${ }^{8}$. The styloid process was carefully dissected with the $5 \mathrm{~mm}$ spatula monopolar from the surrounding connective tissues and the internal carotid artery (Fig. 1D). Prudent blunt dissection was done with cottonoid gauze placed posteriorly to the styloid process
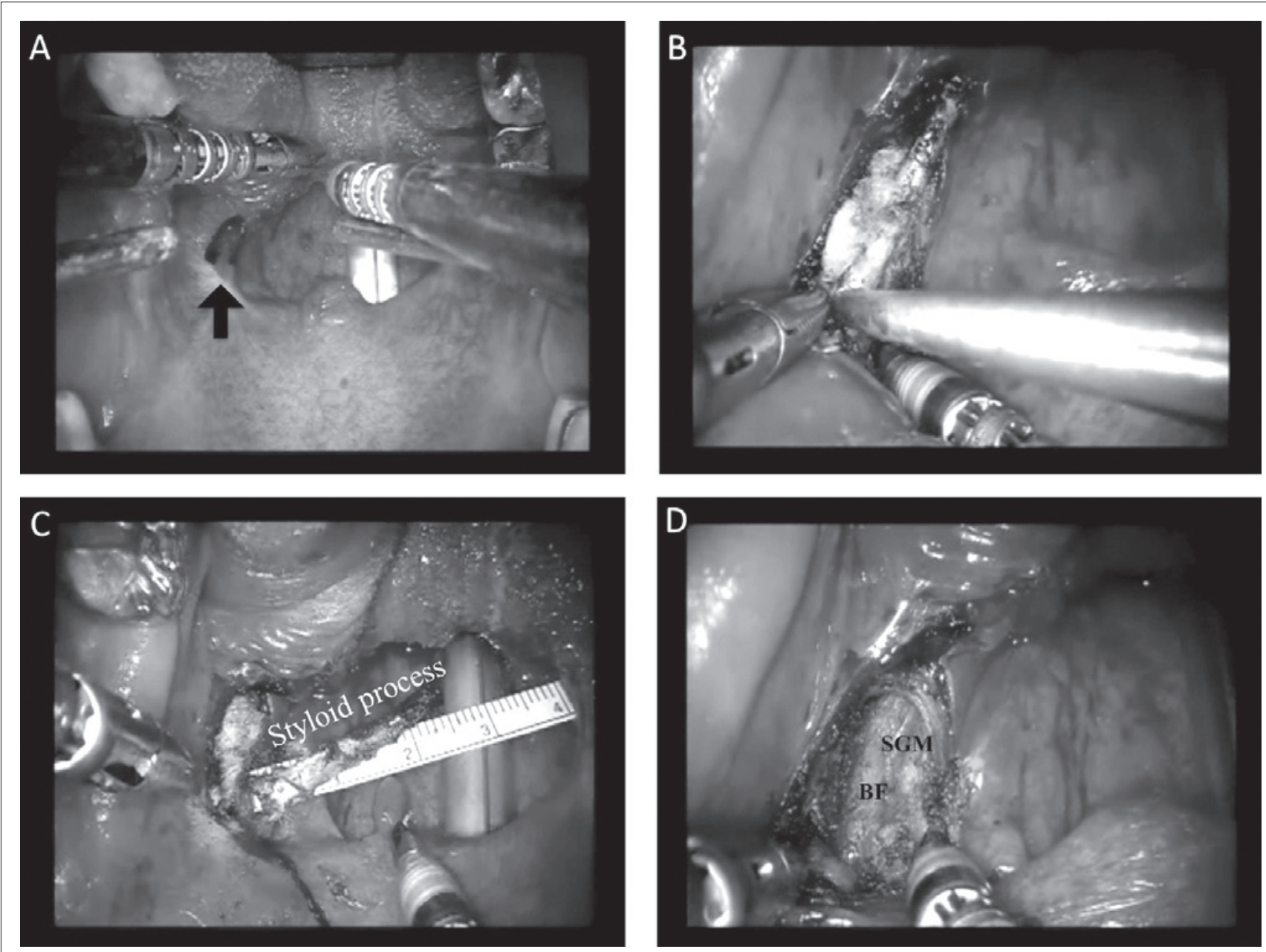

Fig. 1. Operative field of view of the robot. A) Robotic setting. Maryland forceps, spatula monopolar cautery, and two suction equipment. Palpable styloid process (black arrow) is marked. B) Styloid process being cut with the rongeur forcep. C) The styloid process measured $3.1 \mathrm{~cm}$. D) Postoperative view after excision of the styloid process. Styloglossus muscle (SGM) and buccal fat (BF) is noted. 

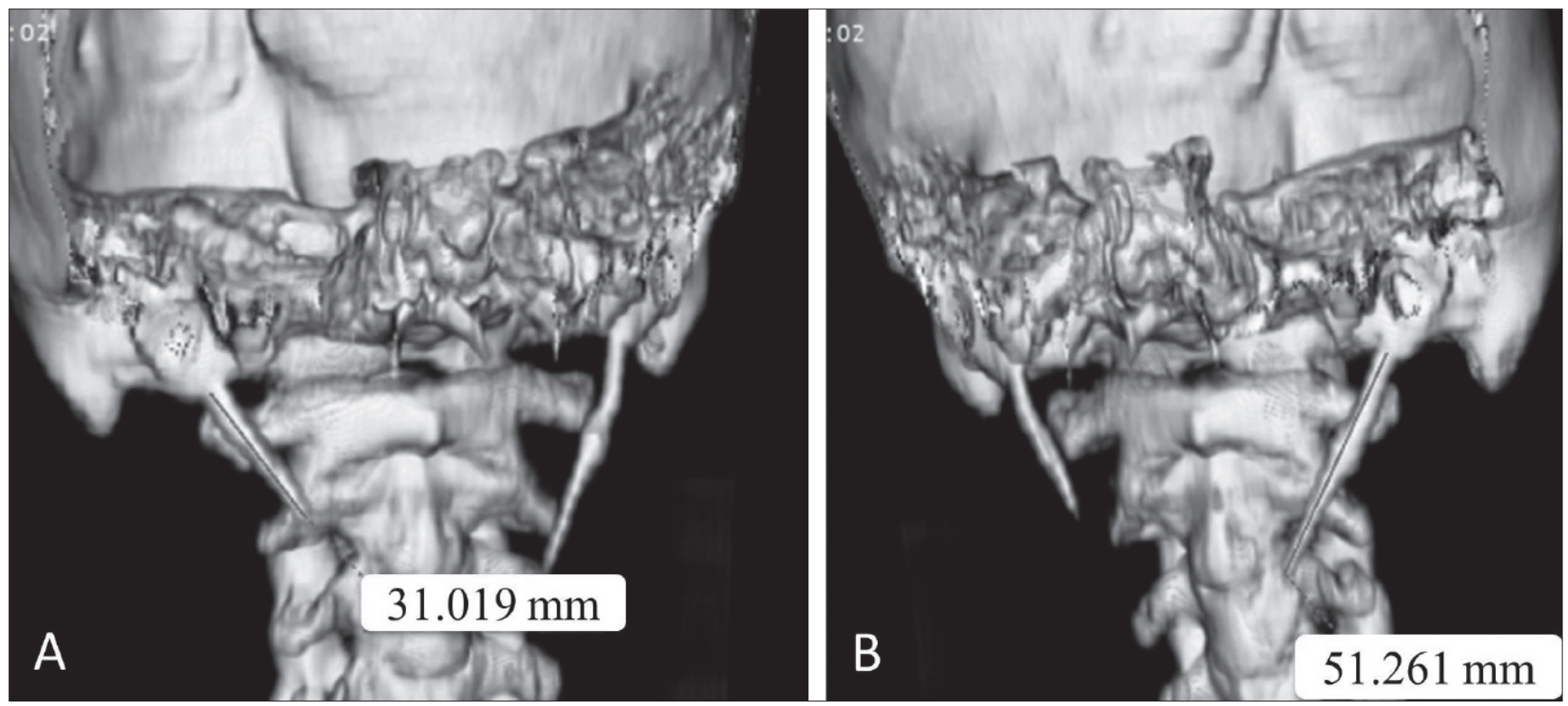

Fig. 2. Preoperative 3D CT of Eagle's syndrome. A, B) Preoperative 3D CT. The left styloid process measured $3.1 \mathrm{~cm}$, while the right was $5.1 \mathrm{~cm}$.

and retracted toward the cephalic direction. When the superior portion was reached, the styloid process was cut by the assistant with the rongeur forceps (Fig. 1B). Bleeding control was done, and the mucosa was sutured with absorbable vicryl. A tonsillectomy procedure was unnecessary for visualisation in three cases; the remaining case had previously undergone tonsillectomy 10 years prior.

\section{Results}

Four patients diagnosed with Eagle's syndrome were treated with transoral robotic surgery. The average age of patients was 53.75 years, and there were equal numbers of males and females. The styloid processes were reconstructed in 3D from the preoperative CT scans (Fig. 2) and were measured as an average of $4.18 \mathrm{~cm}$ (range 3.3-5.1). The set-up for the robotic approach required less than 10 minutes. The operation required approximately 30 minutes with minimal blood loss $(5 \mathrm{~mL})$ in three cases; however, one case required 50 minutes of operation time due to a mucosal bleeding tendency caused by underlying disease.

All patients were completely relieved of symptoms, and were able to restart an oral diet on post-operative day 1
(Table I). No patient suffered intraoperative or postoperative complications such as cranial nerve injury, postoperative bleeding, or deep neck infection.

\section{Discussion}

Due to variable and nonspecific symptoms, Eagle's syndrome is difficult to diagnosis; thus, the prevalence of the syndrome is underestimated in the general population. However, once a diagnosis is made, the treatment of Eagle's syndrome can be either non-surgical or surgical 1910 . Various non-surgical treatments such as steroid injection or long-acting analgesics have been used, but long-term symptom relief has been difficult to achieve with these approaches. For patients who do not respond to medical treatments, a transoral or transcervical surgical approach has been shown to be the most satisfactory and effective treatment ${ }^{14}$.

Transoral approaches have been thought to be 'blind' in that they can damage the neurovascular structures and have been heavily criticised because of the increased risk of deep space neck infection and poor visualisation of the surgical field ${ }^{11}$.

Table I. Clinical characteristics of cases.

\begin{tabular}{|c|c|c|c|c|c|c|c|c|c|c|c|c|}
\hline Case & $\begin{array}{c}\text { Age } \\
\text { (years) }\end{array}$ & Sex & Diagnosis & $\begin{array}{c}\text { Styloid } \\
\text { process } \\
\text { length }(\mathrm{cm})\end{array}$ & $\begin{array}{l}\text { Set-up } \\
\text { time } \\
\text { (minutes) }\end{array}$ & $\begin{array}{l}\text { Operation } \\
\text { time } \\
\text { (minutes) }\end{array}$ & $\begin{array}{l}\text { EBL } \\
(\mathrm{mL})\end{array}$ & $\begin{array}{l}\text { Follow- } \\
\text { up } \\
\text { (month) }\end{array}$ & $\begin{array}{c}\text { Oral } \\
\text { diet } \\
\text { (days) }\end{array}$ & $\begin{array}{c}\text { Hospital } \\
\text { stay } \\
\text { (days) }\end{array}$ & $\begin{array}{l}\text { Preop } \\
\text { VAS }\end{array}$ & $\begin{array}{c}\text { Postop } \\
\text { VAS }\end{array}$ \\
\hline 1 & 57 & $\mathrm{~F}$ & Elongated styloid process & 4.8 & 4 & 35 & 5 & 55 & 1 & 4 & 9 & 1 \\
\hline 2 & 55 & $\mathrm{~F}$ & Elongated styloid process & 3.1 & 9 & 33 & 5 & 36 & 1 & 4 & 9 & 2 \\
\hline 3 & 38 & M & Elongated styloid process & 5.1 & 9 & 29 & $<10$ & 13 & 1 & 3 & 8 & 1 \\
\hline 4 & 65 & $M$ & Elongated styloid process & 3.5 & 5 & 50 & 60 & 15 & 2 & 10 & 10 & 1 \\
\hline
\end{tabular}

VAS scores: $0=$ none, 5 = moderate, $10=$ severe EBL, estimated blood loss; F, female; $M$, male. 
External approaches might give a lower possibility of deep neck infections and improved exposure than a classic naïve transoral approach. However, these invasive methods require more time than the transoral approach and can leave the patients with a visible scar on the face or neck ${ }^{1112}$. In a transoral approach with the robotic system, the robot's endoscopic view offers a 15- to 20-fold magnified view, enabling the surgeon to easily distinguish even tiny neurovascular structures from soft tissue. This magnified view and $360^{\circ}$ rotating instruments provides surgical safety with regards to preservation of neurovascular structures without iatrogenic injury ${ }^{8}$. It should be noted that none of the cases experienced neurovascular injury, deep cervical infection, or failure to complete the procedure from an intraoral approach.

Transoral robotic surgery has advantages over conventional transoral surgery in that the assistant can have the same view as the operator, and the operator can be in control of four arms: two robotic arms and the two assistant's arms. The endoscope can also be closely approached stably and rotated during bone resection, allowing maximal resection of the styloid process. This allows sequelae caused by the remnant styloid process to be minimised.

Nonetheless, there is controversy regarding the robotic approach due to the cost burden on the patient. However, its advantages and the surgical convenience of this approach make it a favourable treatment option for Eagle's syndrome with safe and satisfying results.

\section{Conclusions}

In conclusion, given the superb visualisation and effective preservation of the ICA and neurovascular structures, transoral excision of the styloid process via a robotic approach is a safe surgical alternative treatment option for Eagle's syndrome.

\section{References}

1 More CB, Asrani MK. Eagle's syndrome: report of three cases. Indian J Otolaryngol Head Neck Surg 2011;63:396-9.

2 Eagle WW. Symptomatic elongated styloid process; report of two cases of styloid process-carotid artery syndrome with operation. Arch Otolaryngol 1949;49:490-503.

3 Costantinides F, Vidoni G, Bodin C, et al. Eagle's syndrome: signs and symptoms. Cranio 2013;31:56-60.

4 Torres AC, Guerrero JS, Silva HC. A modified transoral approach for carotid artery type Eagle syndrome: technique and outcomes. Ann Otol Rhinol Laryngol 2014;123:831-4.

5 O'Malley BW Jr, Weinstein GS, Snyder W, et al. Transoral robotic surgery (TORS) for base of tongue neoplasms. Laryngoscope 2006;116:1465-72.

6 Weinstein GS, O’Malley BW Jr, Snyder W, et al. Transoral robotic surgery: supraglottic partial laryngectomy. Ann Otol Rhinol Laryngol 2007;116:19-23.

7 Byeon HK, Duvvuri U, Kim WS, et al. Transoral robotic retropharyngeal lymph node dissection with or without lateral oropharyngectomy. J Craniofac Surg 2013;24:1156-61.

8 Park YM, De Virgilio A, Kim WS, et al. Parapharyngeal space surgery via a transoral approach using a robotic surgical system: transoral robotic surgery. J Laparoendosc Adv Surg Tech A 2013;23:231-6

9 Strauss M, Zohar Y, Laurian N. Elongated styloid process syndrome: intraoral versus external approach for styloid surgery. Laryngoscope 1985;95:976-9.

${ }^{10}$ Chase DC, Zarmen A, Bigelow WC, et al. Eagle's syndrome: a comparison of intraoral versus extraoral surgical approaches. Oral Surg Oral Med Oral Pathol 1986;62:625-9

11 Al Weteid AS, Miloro M. Transoral endoscopic-assisted styloidectomy: how should Eagle syndrome be managed surgically? Int J Oral Maxillofac Surg 2015;44:1181-7.

12 Muderris T, Bercin S, Sevil E, et al. Surgical management of elongated styloid process: intraoral or transcervical? Eur Arch Otorhinolaryngol 2014;271:1709-13. 